\title{
Anela Ilijaš
}

\section{A comparison of the motifs of artist's obsession in „The Tattooer" by Tanizaki Jun'ichirō and „Tale of a Mad Painter" by Kim Dong-in}

\author{
Izvorni znanstveni rad \\ Original scientific paper \\ UDK 821.521.09Juri'ichiro:821.521.09Dong \\ https://doi.org/10.32728/tab.18.2021.6
}

\begin{abstract}
This paper discusses similarities in the choices of plots and motifs in the short stories The Tattooer (1910) by Japanese writer Tanizaki Jun'ichirō and Tale of a Mad Painter (1935) by Korean writer Kim Dong-in, and hypothesizes a possible connection between them. In order to find out whether these works are really connected, common literary influences on both stories and analyzed stories' structures and motifs were compared in this thesis. Results revealed that these two works were written under the influence of the same literary works: the theme of the relationship between art and violence and the motif of the artist obsessed with the desire to create an artistic masterpiece in The Tattooer and Tale of a Mad Painter are most likely inspired by Oscar Wilde's novel The Picture of Dorian Gray and Edgar Allan Poe's short story The Oval Portrait, while motifs of sexual perversions are inspired by Psychopathia Sexualis by Richard Freiherr von Krafft-Ebing. Not only two stories were written under the same influences, but the story Tale of a Mad Painter itself intertextually reworked Tanizaki's The Tattooer adjusting motifs to Korean realities and making the structure more complex.
\end{abstract}

Key words: modern Japanese literature, modern Korean literature, Tanizaki Jun'ichirō, Kim Dong-in, The Tattooer (Shisei), Tale of a Mad Painter (Kwanghwasa) 


\section{INTRODUCTION}

Speaking about Japanese modern literature, Tanizaki Jun'ichirō's name is one of the first names that undoubtedly has to be mentioned. One of the most popular Japanese prose writers in the West, Tanizaki Jun'ichirō is wellknown for masterfully portraying psychological situations in his novels and plays. A brilliant virtuoso of stylization and aestheticism, he is one of the most important figures in the history of Japanese literature. His significance in Japanese modern literature could be compared to the significance of author Kim Dong-in in Korean modern literature. Kim Dong-in's opus is one of the most interesting phenomena in Korean literature of the first half of the 20th century. He is famous for innovating Korean fiction's language and playing an important role in the development of Korean modern literature. Both writers were active on the literary scene of East-Asia in the first half of the 20th century, though Tanizaki started writing earlier since he was born 14 years earlier than Kim Dong-in. Though not major works of either author, both Tanizaki Jun'ichirō and Kim Dong-in at one point in their literary careers had written short stories in which the plot centers around a main character who is an artistic persona driven by a bordering-on-madness desire to create a masterpiece: Tanizaki Jun'ichirō's The Tattooer (Shisei) in 1910, and Kim Dong-in's Tale of a Mad Painter (Kwanghwasa) in 1935. After reading these two short stories, anyone would notice some similarities in their plot, motifs, and structure. While Tanizaki Jun'ichirō's The Tattooer and Kim Dong-in's Tale of a Mad Painter are individual artistic works with their own uniqueness, it seems like there is a connection between them. This assumption is also briefly mentioned in the works Empire of texts in motion: Chinese, Korean, and Taiwanese transculturations of Japanese literature (2009) by K.L. Thornber and Kim Tongin Yeongu (1985) by C. Kim. However, since this assumption is not elaborated in detail, the purpose of this research is to try to reveal the connection between the short stories by comparison of the common literary influences on both authors through analysis of the literature dealing with the oeuvres of these authors and of the stories' structures, motifs, and plot development.

\section{STATEMENT OF THE PROBLEM}

In the works The Tattooer by Tanizaki Jun'ichirō and Tale of a Mad Painter by Kim Dong-in, similarities can be found in the authors' choices of motifs and structure. Justifying the title $A$ comparison of the motifs of artist's 
obsession in "The Tattooer" by Tanizaki Jun'ichirō and "Tale of a Mad Painter" by Kim Dong-in: this research study will present a comparison of the two short stories focusing on their motifs and structure, and provide insight into various literary influences on both stories through an analysis of the literature dealing with the oeuvres of each of these authors. My hypothesis is that these two stories have a connection, they were written under the influence of the same literary works, and The Tattooer by Tanizaki Jun'ichirō had an influence on Kim Dong-in's Tale of a Mad Painter.

\section{METHODOLOGY}

In order to achieve the research aim of this thesis, two types of literary theories were chosen. One is intertextual approach and it belongs to the category of extrinsic approaches. The encyclopedia of literary and cultural theory (Ryan, et al., 2011, p.641) defines intertextuality as the text's relations to other texts in the larger "mosaic" of cultural practices and their expression. It will be used for examining the causal connections between the literary works and the background behind them, such as the influence of one author on another and external influences. The second theory used in this research is the narrative theory, which belongs to the category of intrinsic approaches. Mentioned in The encyclopedia of literary and cultural theory (Ryan, et al., 2011, p.348), literary critic and formalist Boris Tomashevsky explains literary motifs as elementary and irreducible particles of theme and emphasizes that it is the relationship between themes and motifs that gives fiction its narrative form. This motif-based approach will be used for analyzing literary motifs and structures in examined works in the comparative perspective. Combining both extrinsic and intrinsic approaches in this research will help to attain full understanding of the context and connections of the examined works.

\section{BIOGRAPHICAL NOTES ON THE AUTHORS}

\subsection{TANIZAKI JUN'ICHIRO}

Tanizaki Jun'ichirō ${ }^{1}$ (1886, Tokyo - 1965, Yugawara) was a Japanese writer. Tanizaki was born into the family of a wealthy owner of a printing house in Tokyo. Tanizaki had a very happy childhood: he was loved and spoiled

1 In Japanese and Korean languages, the surname comes before the given name, so all Japanese and Korean names mentioned in this thesis are written according to this form. 
by his parents. However, after some time, his father went bankrupt and his family started facing financial hardships. He studied at the Department of Literature at Tokyo Imperial University, but was forced to leave school in 1911 when financial difficulties did not allow him to continue to pay for his studies. Tanizaki Jun'ichirō began his literary career in 1909 when his one-act stage play was published in a literary magazine. At the beginning of his literary career, Tanizaki was greatly inspired by Western literature and culture. His early works are marked by reminiscences of works of Western romanticism and decadence. In addition, Tanizaki was one of the prominent representatives of the Japanese literary Aesthetic movement tanbiha. The most prominent works of this phase include the short story analyzed in this paper The Tattooer (Shisei) and the novel Naomi (Chijin no ai). In later years, Tanizaki Jun'ichirō devoted himself to unique Japanese literature. Western literary influence in his works faded, and, inspired by classical Japanese literature masterpieces such as the medieval novel The Tale of Genji (Genji monogatari) by Murasaki Shikibu, he has created unique works focusing on describing Eastern aesthetics and psychology. The most prominent works of this phase are the novels of The Makioka Sisters (Sasameyuki) and Captain Shigemoto's Mother (Shōshō Shigemoto no haha). In 1964, a year before the writer's death, Tanizaki was nominated for the Nobel Prize in Literature - he was one of six authors on the final shortlist, though he did not win the nomination. After Tanizaki's death in 1965, the Japanese publishing house Chūōkōronsha founded a literary award named after him, which is still considered one of the most prestigious literary awards in Japan in modern times.

(This biographical note was compiled using the data from Remembering Tanizaki Jun'ichiro and Matsuko: Diary Entries, Interview Notes, and Letters, 1954-1989 (2017) by A.H. Chambers and Modern Japanese writers and the nature of literature (1976) by M. Ueda.)

\subsection{KIM DONG-IN}

Kim Dong-in² (1900, Pyongyang - 1951, Seoul) was a Korean writer. He was a son of a wealthy landowner and attended a Christian school since childhood. In 1914 he began studying in Japan at the private university Tokyo Gakuin. Due to its closure in 1915, he transferred to Meiji Gakuin

2 Kim Dong-in is the author's name romanized according to Revised Romanization of Korean; in some sources, his name is romanized as Kim Tong-in according to McCune-Reischauer romanization. 
in Tokyo, where he developed an interest in film and literature. Because of his father's death, he returned to Korea in 1917 and inherited his fortune. The next year he got married and went to study in Japan again, this time to study aesthetics. After the so-called „Declaration of Independence“ was signed by Korean students studying in Tokyo, the Japanese authorities arrested a number of students, including Kim Dong-in. Inspired by the idea of l'art pour l'art (art for art's sake), in 1919 he began to publish the Aesthetic movement's magazine Creation (Changjo) - the first Korean literary magazine. In Creation he published his first novella titled $A$ Sorrow of the Weak (Yakhanjaui seulpeum) (though his first literary attempt was a 1916 tale in Japanese composed for class circulation). He was a significant innovator of Korean fiction's language and an expert in Korean colloquial language. Along with another Korean author, Yi Kwang-su, Kim Dong-in is considered to be a pioneer of Korean modern literature because he played a consequential role in the development of modern literature in Korea by associating narrative devices with modern fiction. These included the establishment of the past tense or the third-person narrator as features of Korean fiction and the elimination of elements of premodern narrative technique. The best works of the author are considered to be the short stories Potato (Gamja), A Sorrow of the Weak (Yakhanjaui seulpeum), Sonata Appassionato (Gwangyeom sonata) and The Seaman's Chant (Baettaragi). Seen from a historical perspective, Kim Dong-in's works are of great significance because they reflect the dark times of colonial oppression in Korea when society suffered from the loss of national identity and suppression of national culture. In his later years, Kim Dong-in had a difficult fate - he suffered from financial problems and was imprisoned for crime against the Japanese emperor. He died at the age of fifty due to meningitis and multiple other illnesses. In 1955, four years after his death, Korean magazine Sasangye established the most famous Korean literary award named after Kim Dong-in (currently run by the newspaper Chosun Ilbo where the author himself worked for some time).

(This biographical note was compiled using the data from Naturalistic sensibility and modern Korean literature: Kim Tongin (2008) by H. Kim and Twentieth-Century Korean Literature (2005) by N. Yi, C. U, K. Yi, and M. Kim) 


\section{COMMON LITERARY CHARACTERISTICS AND INFLUENCES ON BOTH STORIES}

\subsection{AUTHORS' THOUGHTS ON LITERATURE'S PURPOSE}

Looking at Tanizaki Jun'ichirō's and Kim Dong-in's oeuvres one can easily notice the fact that both authors shared similar ideas and thoughts on literature's purpose and its place in society, which also can be seen from the following passage. Around the time when Tanizaki was at the start of his literary career, many Japanese contemporary writers were inspired by the movement of naturalism and supported the idea of art only being acceptable as a copy of a real life. Tanizaki strongly disagreed with this idea and, to express his thoughts on this matter, he wrote the following sentences in 1918: „Would a writer, even a naturalistic writer, be able to present truth if he were lacking in imaginative power? How could art exist if imagination were eliminated from the realm of art? In my opinion, only those who live by their imaginations are qualified to become artists. The artist's imagination may wander far from nature. But as long as it is a living, moving power in his brain, isn't it just as real as any other natural phenomenon? The artist justifies his existence only when he can transform his imagination into truth (Tanizaki, 1966b, p.39)." In 1919 he wrote the essay titled Random Thoughts on an Early Spring Day (Sōshun zakkan), where he came back to this topic and defended his opinion by saying that even the most excellent naturalists like Émile Zola and Gustave Flaubert had written works like Paris and Salammbo, which he thought were extraordinarily imaginative and could only have been written by highly imaginative writers (Ueda, 1976, p.55). Around the same time, Kim Dong-in was also involved in a literary polemic, but on a slightly different topic. Namely, his opponent was Yi Kwang-su, a well-known Korean writer of that time who viewed literature as a tool for enlightening the Korean people. He believed that educational topics should be promoted in fiction. He became famous in Korea as a didactic writer and his views are expressed in his most successful novel The Heartless (Mujong), which he wrote in 1917. On the other hand, Kim Dong-in, inspired by the idea of l'art pour l'art (art for art's sake), rejected didacticism in literature and issued an attack on Yi Kwang-su stating that literature is not intended to propagandize certain ideas, whether they are didactic, moral, political, or otherwise. To him, literature had no other purposes than the artistic one. He was emphasizing the autonomy of literature as art and the purity of literary creation. Interestingly, in his critique towards Yi Kwang-su's enlightenment literature he stated some thoughts which were very similar to Tanizaki's abovementioned thoughts on naturalistic movement in the literature. Namely, Kim 
Dong-in, though often called a naturalist writer, strongly disagreed with the fact that literary fiction must provide an exact reflection of reality, just as Tanizaki did. Yi, et al. (2005, p.10) state that to Kim Dong-in "fiction writing was an act of artistic creation rather than an exercise in imitation of lived reality; the world contained in a work of art was 'one's own created world."' His opinion that world in the art is "one's own created world" reminds of another Tanizaki's passage written on another occasion: "I believe that things which have never happened in this world can be made to happen by means of art. In my opinion, a novelist should aim ultimately at constructing an autonomous universe in his work (Tanizaki, 1966a, p.497)."

\subsection{COMMON LITERARY CHARACTERISTICS: DEMONIC AESTHETICISM}

Tanizaki and Kim Dong-in not only shared the same thoughts on literature's purpose, but also shared some literary characteristics in their writings as well. One of the most noticeable characteristics of Tanizaki's and Kim Dong-in's works is demonic aestheticism, which can be found in the cruel acts of the main characters in The Tattooer and Tale of a Mad Painter. Both Seikichi from The Tattooer and Solgeo from Tale of a Mad Painter are artists who use violence to create their masterpieces. Praising sophisticated aestheticism, they are ready to sacrifice someone's pain or even life for the art. Violence is romanticised in their acts and, erasing the boundaries of moral and immoral, is even portrayed as a necessity in order to create art. Darkness and violence are the motifs that are recurrent in the oeuvre of both authors. Even so, these motifs had different origins. Tanizaki was admiring daemonic beauty, particularly the beauty of cruelty, because he was highly interested in psychology, especially human's subconscious, and he considered it as mainly destructive (Ueda, 1976, p.69). In Kim Dong-in's case, this demonic aestheticism was the author's reflection of difficult, dark times Korean society was going through during the period of colonial oppression (Yi, et al., 2005, p.11).

\subsection{COMMON LITERARY CHARACTERISTICS: DETAILED CHARACTERIZATION}

As it was mentioned above, Tanizaki had a strong interest in psychology, thus it was crucial for him to create comprehensive psychological portraits for the characters of his stories, which can be seen from the following passage 
he once wrote as well: "One of the things I am currently interested in doing is to delineate the psychology of a Japanese woman of the feudal period, without giving it a modern interpretation and yet with such verisimilitude as to appeal to the modern reader's emotions and understanding. I want to draw a truly lifelike portrait of a woman who believed in the neo-Confucian moral codes and who was therefore bound by them - a woman of bygone days who was reserved in all things, who was taught to suppress her feelings on all occasions, and who seldom showed her face to any person of the opposite sex except her husband (Tanizaki, 1966a, pp.408-409)." From this quote it can be seen how precise Tanizaki was when creating characters, so that readers can understand and feel them and their motivation. Just like Tanizaki, Kim Dong-in really cared about creating sui generis characters and the psychological aspect was very important to him. It can be also seen in Tale of a Mad Painter: the author explains his main character's life circumstances and writes down his thoughts in order to craft a more realistic character. Besides creating developed psychological portraits, another distinctive feature of Kim Dong-in's writings is the use of painterly details in the description of the literary portrait. Kim Dong-in was the first Korean author who made the connections between the physical appearance and personality in the literary portrait much more complicated than in the traditional Korean literature where characters' physical appearance usually directly depended on their personality: heroes and heroines were always good-looking and beautiful, while villains were ugly and scary. The portrait of each character in Kim Dong-in works is individualized and endowed with unique features that let the character be one of a kind. These features do not show a character's social (or any other) status, but their individuality (Park, 2012, p.154-155). Therefore, it can be said that another common characteristic of Tanizaki's and Kim Dong-in's works is detailed characterization, describing both a characters' appearance and personality traits.

\subsection{COMMON LITERARY INFLUENCES: RICHARD FREIHERR VON KRAFFT-EBING}

Both Tanizaki and Kim Dong-in included sexual motifs in many of their works. While those were not always explicit, they often had a perverted connotation. Yi, et al. (2005, p.10) think that sexual desire in Kim Dong-in's works lies outside the boundaries of socially accepted norms, while Ueda (1976, p.58) mentions that to Tanizaki sex was both a constructive and destructive force in the human subconscious. It seems like Tanizaki's and 
Kim Dong-in's perverted sexual motifs put in the context of psychological characterization were under the same influence - and that influence was the book titled Psychopathia Sexualis. Psychopathia Sexualis by AustroGerman psychiatrist Richard Freiherr von Krafft-Ebing was first published in 1886 as one of the earliest published studies of sexual pathologies. This book has attracted the attention of intellectuals from around the world because it includes detailed medical reports on a huge number of cases of sexual deviations (many of them described for the first time) collected by Krafft-Ebing himself. Psychopathia Sexualis immediately became widely known and was translated to many languages, including Japanese. In Japan this book was translated as Hentai Seiyoku Shinri and was published in 1913 by Japan Civilization Society (Dainippon Bunmei Kyōkai), which was publishing Japanese translations of many famous Western literary works with the didactic purpose at that time (Hatano, 2011, p.420). Japanese intellectuals were also stirred by this publication - Psychopathia Sexualis caused many discussions and disputes. Tanizaki Jun'ichirō was one of these intellectuals who have read Psychopathia Sexualis and were deeply impressed by it. Morton (2009, pp.117-118) states that Tanizaki was influenced by Psychopathia Sexualis to the point where he even made mention of it in his 1914 novel Jötarō, known as a novel with autobiographical elements: „Nevertheless, when he was in the first year of his Humanities course at university, by chance he perused a volume by Krafft-Ebing. How great was Jōtarō's amazement, joy, and excitement at that time? This was the first time he had received such a frightening and powerful shock from a book by a human being the same as himself. As he turned the pages and read, a violent shivering spread through his entire body that he was powerless to prevent..." Sadomasochism, elaborately described in Psychopathia Sexualis, appears implicitly or explicitly in many Tanizaki's works and The Tattooer, whose protagonist Seikichi is a sadist who enjoys torturing people and admires cruelty in women, is one of them. As mentioned above, official Japanese translation of Psychopathia Sexualis was published only in 1913, 3 years later than The Tattooer was published, but Inoue (2002, p.15) states that there was an authorized English translation of Psychopathia Sexualis by F. J. Rebman and some abridged translations available to Tanizaki earlier. Therefore, interpreting the mentioned-above quote from Jōtarō as an autobiographical description suggests that Tanizaki himself "received a frightening and powerful shock" after he first read the English translation of Psychopathia Sexualis around 1908. Hatano (2011, pp.420-421) believes that Kim Dong-in, who was studying in Japan and had read many Western books in Japanese 
translation, also was influenced by Krafft-Ebing's Psychopathia Sexualis. It could be proved by the fact that he wrote a critique titled Sexual Perversion and the fact that he included some of the cases described in Psychopathia Sexualis in his novels. There are some of Kim Dong-in's works where the sexual topic is more explicit, e.g. Sonata Appassionato (Gwangyeom sonata) and Potato (Gamja), but there are motifs of perversion in Tale of a Mad Painter as well: protagonist Solgeo had an idealized standard of beauty based on his memories of his own mother and suffered because of forced abstinence for many years, so when he finally encountered a woman who was not disgusted with his presence, he trembled with desire to have her. To sum up, it seems that both the tattooer Seikichi, who had sadistic desires and a foot fetish, from The Tattooer and the painter Solgeo, who idealized his own mother's beauty and suffered from forced abstinence, from Tale of a Mad Painter were the fruit of the imagination of Tanizaki Jun'ichirō's and Kim Dong-in's minds influenced by Krafft-Ebing's work.

\subsection{COMMON LITERARY INFLUENCES: OSCAR WILDE}

Krafft-Ebing's Psychopathia Sexualis was not the only book which both authors had read. It can be seen from Tanizaki's and Kim Dong-in's essays and letters that they both read many famous Japanese authors, like Natsume Sōseki, Shimazaki Tōson et al., and prominent Western authors, like Émile Zola, Fyodor Dostoevsky, Leo Tolstoy, et al. However, their opinions on some authors didn't always coincide - for example, Kim Dong-in highly respected Shimazaki Tōson, a fellow graduate of Tokyo's Meiji Gakuin (Thornber, 2009, p.37), while Tanizaki “detested Tōson” and said "I'm not impressed; it doesn't appeal to me" after reading Tōson's novel Before the Dawn (Yoakemae) according to his wife Morita Matsuko (Chambers, 2017, p.80). Nevertheless, both Tanizaki Jun'ichirō and Kim Dong-in greatly admired Irish writer Oscar Wilde's oeuvre. Tanizaki on several occasion mentioned that Wilde was one of his literary mentors and even began his short story The Cursed Play (Norowareta Gikyoku) with Wilde's quote: „Nature imitates art.“ Kim Dong-in also loved Wilde, whose works he discovered while studying in Japan reading them in Japanese translation. The earlier-mentioned fact that he was a devotee of the Aesthetic movement's theory l'art pour l'art was mostly inspired by Oscar Wilde, who was one of the most famous spokesmen for the Aesthetic movement that supported the idea of l'art pour l'art. For this research it is important to mention Wilde's 1890 novel The Picture of Dorian Gray 
because it was most likely one of the books that had a big influence on both authors when they were writing The Tattooer and Tale of a Mad Painter. Morton (2009, p.113) states that The Picture of Dorian Gray's central motif is the relationship between the artist and art which is supported by many sadomasochistic metaphors that express the power that art exerts over the artist and notices that Tanizaki also uses the same main motif and sadomasochistic metaphors of control and slavery in The Tattooer. Hatano (2011, p.424) believes that Kim Dong-in was influenced by Wilde's The Picture of Dorian Gray as well, and that he adopted many ideas, like the motif of the girl who loses her beauty and dies because of love, from it in his Tale of a Mad Painter. Thornber (2009, p.454) also states that some critics have noticed similarities between The Picture of Dorian Gray and Tale of a Mad Painter (and Kim Dong-in other story Sonata Appassionato), but she points out that, while in The Picture of Dorian Gray violence is facilitated by the artistic masterpiece, Tale of a Mad Painter (and Sonata Appassionato) portray violence as „art's principal stimulus."

\subsection{COMMON LITERARY INFLUENCES: EDGAR ALLAN POE}

There is one more Western author who probably had an influence on Tanizaki and Kim Dong-in when they were writing their stories about mad artists: American writer and poet Edgar Allan Poe. Thornber (2009, p.454) mentions that Tanizaki's The Tattooer (and some other Japanese short stories) are reminiscent of Edgar Allan Poe's 1842 short story The Oval Portrait. In The Oval Portrait the narrator spends time looking at paintings in an abandoned chateau where he had decided to spend the night, and checks their descriptions written in the book he finds there. He notices a painting of a beautiful young girl and he is stunned by how realistic that painting is. In the description book he reads a tragic story behind this portrait - it is a portrait of a painter's wife. Her husband, who cared about his art the most, had decided to draw her, so she obediently sat in front of him for many weeks, even though her health was fading with every day. When the painter finally finished the painting, shocked that the portrait looked like "Life itself", he realized his wife had died. Most likely Tanizaki had read this story - he was a big admirer of Poe and many of his early works are reminiscent of Poe's oeuvre. Along with Wilde, Poe was one of the authors that greatly influenced Tanizaki's works in the first period of his literary career, so the motif of the obsessed artist who is ready to sacrifice a young female's beauty for art from The Tattooer could be inspired 
by the motif of the obsessed painter-husband from The Oval Portrait. It is possible that this motif inspired Kim Dong-in to write his short story as well. Just like Poe, Kim Dong-in used the "story within a story" literary device: in Poe's The Oval Portrait, the story about the painter is written in the book the narrator finds in the chateau, and in Kim Dong-in's Tale of a Mad Painter the story about the painter is made up by the narrator during his afternoon stroll. Also, in both Poe's and Kim Dong-in's stories the last part of the portrait left before finishing the painting are girls' pupils.

\subsection{TANIZAKI'S INFLUENCE ON KIM DONG-IN}

Lastly, the question that naturally comes to our minds is whether Tanizaki Jun'ichirō himself had an influence on Kim Dong-in. The answer is yes. Kim Dong-in was studying in Japan from 1914 to 1919 (except 1917 when he had to come back to Korea to inherit his fortune following his father's death (Kim, 2008, p.6) ) and used the time there to read many modern Japanese and Western authors' works, including The Tattooer which was published four years before Kim Dong-in came to Japan (Gil, 2019, pp.247-248). Japanese literature played a big role in forming his literary style, even to the point that he wrote his first work in Japanese language in Japan, and Tanizaki was one of the Japanese authors who had an influence on Kim Dong-in. It can be seen from Kim Dong-in's references to Tanizaki's works that he had a big interest in his oeuvre and was influenced by him (Gil, 2019, p.248). Thornber (2009, p.454) also thinks that Kim Dong-in intertextually reworked Tanizaki's The Tattooer in his Tale of a Mad Painter.

\section{COMPARISON OF THE STORIES' STRUCTURES AND MOTIFS}

For the purposes of analysis of The Tattooer and Tale of a Mad Painter, these stories can be divided into smaller structural units that have similar motifs and plot development. I have decided to divide them into the six following parts: 1) setting the historical period where the main character lives, 2) introducing the main character and his passion for art, 3) birth of the artistic desire, 4) looking for the victim, 5) encountering the victim, 6) realization of the main character's artistic desire. There will be an overview of each part referring to similarities and differences between the stories' plots and motifs. 


\subsection{PART 1: SETTING THE HISTORICAL PERIOD}

Both authors start their stories by placing the main characters in the specified historical periods, thus showing to readers that their main characters are characters from the past, not the readers' contemporaries. Tanizaki decided to put his main character Seikichi into the city of Edo (former name of Tokyo) in the Edo period (1603-1868): a period of economic growth and political stability under the Tokugawa shogunate which abundantly gifted Japanese culture with kabuki, bunraku, geisha culture, and ukiyo concept in Japanese literature and art. Kim Dong-in adjusted the story to Korean realities. For his main character Solgeo he chose Seoul in the period of King Sejong the Great's reign, also known in Korea as the Golden Age (1418-1450): a period of prosperity and great accomplishments in the scientific and cultural fields in Korean history when the Korean writing system hangul, the rain gauge, the water clock, celestial globes, and various astronomical maps were invented.

However, comparing this first part in the stories being analyzed, readers can notice a difference in the type of narration. While Tanizaki uses plain third-person narration and immediately sets the historical period as an external narrator, Kim Dong-in creates the special narrative character Yeo and starts the story by describing the narrator's afternoon stroll. It is narrative character Yeo in Tale of a Mad Painter who decides to think up the story about the painter living during King Sejong's reign Kim Dong-in used the "story within a story" literary device to make the structure more complex. By applying this literary device he managed to present to the readers two stories at once: one story about a man having an afternoon stroll, and other story about a lonely painter who lost his mind while trying to create a masterpiece, which was, in fact, just a figment of man's imagination that came to his mind during the stroll. The "story within a story" device is usually used in literature to create different spatio-temporal settings and it enables the author to immerse readers in the story deeply than using plain third-person narration can. Kim Dong-in successfully accomplished that: narrating the tale of a mad painter by using special narrative character Yeo helps readers to become more involved in the story. 


\subsection{PART 2: INTRODUCTION OF THE MAIN CHARACTER}

After the historical background is set, the authors introduce their main characters to the readers. The Tattooer's main character is young tattooer Seikichi and Tale of a Mad Painter's main character is eremitic painter Solgeo. The biggest similarity between them is obvious: they are both artists and they are both passionate about drawing: one is passionate about drawing on canvas, the other about drawing on human bodies (it is worth mentioning that in the past Seikichi was a painter as well - a painter of the ukiyo-e school). Nevertheless, they were polar opposites in many other aspects. Even though we don't have much information about Seikichi's physical appearance, we know that he is young, while Solgeo is probably in his 50s, which we can conclude from the quote, „almost forty years had passed since Solgeo had embarked upon the path of the artist" (Kim, 1935, p.7). Unlike Tanizaki, Kim Dong-in also provided a detailed portrait of Solgeo's outer appearance - he was unlucky to be born with a very unattractive and displeasing appearance. For that reason he decided to live in the seclusion outside of society and avoid interactions with people. In contrast, Seikichi interacts with many people everyday - he is widely known as a very skillfull master, so he has a lot of customers.

In this second part Kim Dong-in mostly focuses on describing Solgeo's appearance and his life story, while Tanizaki puts emphasis on Seikichi's hidden sadistic pleasures in his work, yet both authors create psychological portraits of their protagonists - they give readers an intimate insight into what goes on in their minds.

\subsection{PART 3: BIRTH OF THE ARTISTIC DESIRE}

In the third part of the stories an artistic desire is born in the minds of the main characters. Both Seikichi and Solgeo long to create their best masterpieces. While Solgeo longs to draw a portrait of a perfect woman, Seikichi wants to draw on a perfect woman's body. But they both set very high standards for the woman needed for the creation of the masterpiece.

For Seikichi, "a lovely face and a fine skin were not enough" (Tanizaki, 1910), he wants a woman to have a specific character as well. As Tanizaki mentioned in the first part of the story, Edo period was a time when people truly admired beauty and had a strong sense of aesthetics. For instance, 
tattoo exhibitions, mentioned in the story, where men would show off their tattooed bodies and boast of their own new designs proved the importance of impressive appearance in society during that time. Seikichi was one of those aesthetes, and for that reason he had a refined taste for what is beautiful in appearance and character.

Solgeo's initial desire was to portray a human face because he got tired of painting traditional landscapes imbued with the spirit of antiquity and wanted to paint something new, but gradually his ambitions grew bigger and he decided to portray a beauty "fairer that the fairest woman who has ever lived" (Kim, 1935, p.8).

Tanizaki's description of the "birth" of Seikichi's idea is rather brief, while Kim Dong-in made this part long, writing down the whole process of the desire's growth and Solgeo's thoughts on it.

\subsection{PART 4: LOOKING FOR THE VICTIM}

When the main characters decide for themselves what they are looking for, they start searching. They go outside and begin looking for their ideal beauty.

Seikichi visits all the Edo pleasure quarters to find a woman refined enough for his masterpiece but finds none. Only during the fourth year of his unsuccessful searches he becomes close to his ideal when he happens to see the foot of a beautiful young woman peeping out beneath the curtains of a palanquin in the Fukagawa district. Realizing that only a true beauty can have such a perfect foot, he tries to chase the palanquin, but quickly loses sight of it.

Solgeo also starts his search on the streets, wandering with hope in his heart that he would meet a beauty there. But the women whom he meets there are either maidservants or women of the lower class - they are not refined enough for him, so he decides to have a look in the royal mulberry garden. The court ladies are more beautiful than women of the lower class, but their facial expressions lack the tenderness of Solgeo's deceased mother's eyes.

Both main characters spend a long time looking for their "victims" and do not succeed at first, which strengthens their desire into real obsession. 


\subsection{PART 5: ENCOUNTER WITH THE VICTIM}

In the fifth part of the stories Tanizaki and Kim Dong-in finally let their protagonists encounter their models. In both cases this encounter is completely unexpected.

One year after Seikichi's accidental encounter in the Fukagawa district, the young girl whose foot Seikichi saw that day arrives at his house on an errand for his geisha friend. Just a glance at her legs makes him realize who this girl is. He brings her to his studio to show her two picture scrolls showing cruel and dominant woman who enjoy torturing men: he wants to demonstrate her real personality.

Solgeo meets his unknown beauty when he goes to wash his dinner rice in the stream. The girl happens to be blind, so she is not disgusted by Solgeo's appearance. She talks with him very openly and when Solgeo starts telling her the legend about the palace of the Dragon King, she becomes very interested in it, so the painter easily persuades her to go to his hut.

Speaking of similarities in this part, both Seikichi and Solgeo meet their models after many years of searching. In The Tattooer four years have passed since Seikichi started his search until the moment when he saw a foot of young lady in the palanquin and one more year until he finally met the girl - five years of searching in total. In Solgeo's case he met the girl even later - after ten years. Also, both girls are very young - the girl in The Tattooer is only "fifteen or sixteen," while Kim Dong-in made the girl one year older - "sixteen or seventeen." Therefore, we can conclude that for both Seikichi and Solgeo youth was a very important quality of the ideal woman.

However, the interesting difference between their encounters with the models is that the girl in The Tattooer arrives at Seikichi's house in the morning, while Tale of a Mad Painter's Solgeo finds his "victim" in the evening before dinner. The fact that they met in the evening might be Kim Dong-in's hint that the story has a dark ending. 


\subsection{PART 6: REALIZATION OF THE ARTISTIC DESIRE}

The final part of the analyzed stories narrates the realization of their mad desire through completing their artistic desire. This is the part when the violent side of protagonists eventually comes to light.

Seikichi sedates the girl by an anesthetic and starts the work. To create the best tattoo he has ever made - a tattoo of a huge spider on girl's back - he works for the whole day and night finishing his work only by dawn. Seikichi has feelings for her, even if those are perverted and unhealthy ones, and puts all his soul into completing this work. He feels pain during the entire process of tattooing because every thrust of his needle hurts him as if he were stabbing his own heart. When he finally finishes his work, he feels completely drained having no emotions at all. The girl, who became her true self through Seikichi's art, mercilessly leaves him.

Solgeo fools a girl by lying to her that the fictional palace of the Dragon King is real and that there is a magic pearl which can heal the girl's blindness. The young girl naively listens to his story while Solgeo uses her excitement to paint her. By the point when twilight turns to night Solgeo finishes everything except the pupils of the eyes. Solgeo has feelings for the girl as well, but those are more of a physical nature. Unlike Seikichi who only uses the girl's body for the artistic purpose, Solgeo also spends a night with his model. The next morning the shiny expression of the girl's eyes changes to the expression of a loving woman. Disappointed, Solgeo tries to make her think about the palace of the Dragon King again to return her dreamful look, but unable to do that he goes mad and in a fit of rage he kills her by choking. The fall of her body knocks the ink over and drops of ink spatter such that they finish the painting and express the girl's expression of despair in the moment when Solgeo began to choke her. The painter goes crazy and wanders around clutching the portrait until his last day.

Both artists become violent to create their masterpieces, but Solgeo's violence goes to another level when he commits a murder. That makes the ending of Tale of a Mad Painter darker than the ending of The Tattooer, though both endings have a tragic aftertaste. It seems the reason why Tale of a Mad Painter's ending is darker lies in the above-mentioned fact that Kim Dong-in lived in the difficult times of colonial oppression in Korea and also had a difficult fate himself, so the tragic ending of the story was a reflection of tragic events in his life and in his homeland. 


\section{CONCLUSION}

\subsection{COMMON LITERARY INFLUENCES: CONCLUSION}

This paper's purpose was to analyze two short stories, The Tattooer by Tanizaki Jun'ichirō and Tale of a Mad Painter by Kim Dong-in, which plots revolve around an artist obsessed with unhealthy artistic desire, and the common influences under which they were created. As it was assumed in the hypothesis, the two short stories were written under the same literary influences. Tanizaki Jun'ichirō and Kim Dong-in, both among the most prominent representatives of their national literatures, were greatly inspired by Western fiction and non-fiction literature in the early stage of their literary careers, therefore they borrowed some motifs for their works. The theme of the relationship between art and violence and the motif of the artist obsessed with the desire to create an artistic masterpiece in The Tattooer and Tale of a Mad Painter are most likely inspired by Oscar Wilde's novel The Picture of Dorian Gray and Edgar Allan Poe's short story The Oval Portrait. The motifs of sexual perversions in these short stories mirror the deep impression left on both authors by the scientific work of Richard Freiherr von Krafft-Ebing titled Psychopathia Sexualis.

\subsection{INTERTEXTUALITY: CONCLUSION}

The analysis of the structures and motifs in the two stories using the methods of comparison of structural units with similar motifs and plot development helped to realize that not only were the writers inspired by the same works, but the story Tale of a Mad Painter itself intertextually reworked Tanizaki's The Tattooer, which was also predicted in the hypothesis. It is important to mention, however, that the concept of intertextuality, invented by Bulgarian literary scholar Julia Kristeva, has imperfections in terms of defining whether relations between the "original" text and "intertextually reworked" text have to be intentional or to be called so, or unintentional correspondence is called intertextuality as well (Ryan, et al., 2011, pp.641644). The author of this thesis uses the term intertextuality as defined by literary critic Boris Tomashevsky (he used the word convergence which is later translated as intertextuality) who thought that similarities between the literary texts can be divided into three types: 1 ) intentional citation 2) unconscious reproduction of a literary template 3 ) coincidence (Petrova and Kulakova, 2011, p.132). Therefore, while it is impossible to find out whether 
Kim Dong-in did it intentionally or not, if we consider intertextuality as both intentional and unconscious similarities between the texts, Kim Dongin's Tale of a Mad Painter certainly intertextually reworked Tanizaki's The Tattooer. Furthermore, according to Roland Barthes's semiotic theory every text is made by quotations and allusions which were read, heard, or seen by the author of the text at one point in their life (Petrova and Kulakova, 2011, p.132) which also proves that Kim Dong-in, who had read The Tattooer, implemented some allusions to Tanizaki's story in his Tale of a Mad Painter, whether that was done intentionally or unconsciously.

\subsection{COMPARISON OF MOTIFS AND PLOT DEVELOPMENT: CONCLUSION}

Both The Tattooer and Tale of a Mad Painter can be divided into smaller structural units that have similar motifs and plot development: 1) setting the historical period where the main character lives, 2) introducing the main character and his passion for art, 3) birth of the artistic desire, 4) looking for the victim, 5) encountering the victim, 6) realization of the main character's artistic desire. Each of these parts has a similar development of the story - characters commit similar acts and their artistic desire develops into obsession in the same way. Nevertheless, Kim Dong-in adjusted motifs of Edo and its culture to Korean realities, setting his story in Seoul in the period of King Sejong the Great's reign. He also changed the main character's physical appearance and personality, leaving only the crucial common characteristic - obsession hidden in the artist's mind. The length of Tale of a Mad Painter is greater than The Tattooer's length due to more detailed insights into the protagonist's thoughts and more detailed descriptions of every scene. Kim Dong-in also made the narration in his story more complex by introducing the "story within a story" literary device instead of plain third-person narration. Tale of a Mad Painter has a darker and more violent ending than the ending of The Tattooer, probably reflecting tragic events in Korea and in Kim Dongin's life. Of course, despite the fact that Kim Dong-in's Tale of a Mad Painter is reminiscent of Tanizaki Jun'ichirō's The Tattooer, it was created as a selfcontained unique literary work and therefore should be appreciated as one.

Both stories are great examples of Tanizaki Jun'ichirō's and Kim Dongin's brilliant literary talents. In these stories the authors demonstrate their virtuosity in creating detailed psychological portraits, as well as show that 
they are the devotees of aestheticism. Tale of a Mad Painter and The Tattooer each bring up the sensitive topic of the relationship between art and violence and raise the question of how far one artist can go in terms of violence in order to fulfill their artistic desires and create their masterpiece. While it is on readers to decide the answer to that question on their own, Tanizaki Jun'ichirō and Kim Dong-in doubtlessly proved that their stories are of great artistic and literary value.

\section{REFERENCES}

\section{CHAMBERS 2017}

Chambers, A.H., 2017. Remembering Tanizaki Jun'ichiro and Matsuko: Diary Entries, Interview Notes, and Letters, 1954-1989. [e-book] University of Michigan Press.

\section{http://dx.doi.org/10.3998/mpub.9701749}

GIL 2019

Gil, M.H., 2019. Tanizaki Jun'ichirō to Kim Dong-in bungaku ni okeru bi no keisei toshite no mozō. Ilboneomunhag, [e-journal] 87, pp.247-262.

http://dx.doi.org/10.21792/trijpn.2019..87.013 [In Japanese]

HATANO 2011

Hatano, S., 2011. Kaisetsu. In: Kim, D.I. Kim Dong-in sakuhin-shū - Chōsen kindai bungaku senshū 5. Hatano, S. ed. Tokyo: Heibonsha. pp.420-427. [In Japanese]

INOUE 2002

Inoue, K., 2002. Tanizaki Jun'ichirō no seikimatsu. In: M. Matsumura, ed. 2002. Tanizaki Jun'íchirō to seikimatsu. Kyoto: Shibunkaku Shuppan. pp.7-28. [In Japanese]

KIM 1935

Kim D.I., 1935. Tale of a Mad Painter. [e-book] Translated from Korean by S. Epstein and M.Y. Kim, 2013. Literature Translation Institute of Korea. Available at:

Issuu <https://issuu.com/ltilibrary/docs/tale_of_a_mad_painter> [Accessed 10 March 2020].

KIM 2008

Kim, H., 2008. Naturalistic sensibility and modern Korean literature: Kim Tongin. [e-book] Florida State University. Available at: Florida State University Libraries $<$ https://fsu.digital.flvc.org/islandora/object/fsu:254127/datastream/ $\mathrm{PDF} /$ view $>$ [Accessed 10 June 2020]. 
MORTON 2009

Morton, L., 2009. The alien within: representations of the exotic in twentiethcentury Japanese literature. Honolulu: University of Hawaii Press.

PARK 2012

Park, I.L., 2012. Poetika rasskazov Kim Dong Ina. Vestnik Chelyabinskogo gosudarstvennogo universiteta, 33 (287), pp.151-156. [In Russian]

PETROVA AND KULAKOVA 2011

Petrova, N.V. and Kulakova, O.K., 2011. Razlichnye podkhody k opredeleniyu intertekstualnosti. Vestnik Irkutskogo gosudarstvennogo lingvisticheskogo universiteta, 2 (14), pp.131-136. [In Russian]

RYAN ET AL. 2011

Ryan M., Castle G., Eaglestone R. and Booker M.K. eds., 2011. The encyclopedia of literary and cultural theory. [e-book] Wiley Online Library.

http://dx.doi.org/10.1002/9781444337839

\section{TANIZAKI 1910}

Tanizaki, J., 1910. Shisei. [e-book] Aozora Bunko. Available at: Aozora Bunko <https://www.aozora.gr.jp/cards/001383/files/56641_59496.html> [Accessed 10 March 2019]. [In Japanese]

\section{TANIZAKI $1966 \mathrm{~A}$}

Tanizaki, J., 1966a. Tanizaki Jun'íchirō zenshū (dai 20 kan). Tokyo: Chūōkōronsha. [In Japanese]

TANIZAKI 1966 B

Tanizaki, J., 1966b. Tanizaki Jun'ichirō zenshū (dai 23 kan). Tokyo: Chūōkōronsha. [In Japanese]

THORNBER 2009

Thornber, K.L., 2009. Empire of texts in motion: Chinese, Korean, and Taiwanese transculturations of Japanese literature. Cambridge: Harvard University Press.

UEDA 1976

Ueda, M., 1976. Modern Japanese writers and the nature of literature. Stanford: Stanford University Press.

YI ET AL. 2005

Yi, N., U, C., Yi, K. and Kim, M., 2005. Twentieth-Century Korean Literature. Translated from Korean by Y. Ryu. Norwalk: EastBridge. 


\section{SAŽETAK}

\section{Usporedba motiva opsesije slikara u novelama „Tetoviranje“ Tanizakija Jun'ichira i „Lud slikar“ Kima Dong-ina}

Ovaj rad razmatra sličnosti u izboru sižea i motiva u novelama Tetoviranje (1910) japanskoga književnika Tanizakija Jun'ichira i Lud slikar (1935) korejskoga književnika Kima Dong-ina te postavlja hipotezu o njihovoj mogućoj povezanosti. Kako bi pronašla odgovor na pitanje jesu li ta djela zaista povezana, autorica ovoga rada usporedila je zajedničke književne utjecaje na obje novele i analizirala strukture i motive u novelama. Rezultati su pokazali da su oba djela napisana pod utjecajem istih književnih djela: tema odnosa između umjetnosti i nasilja te motiv opsjednutoga željom da stvori remek-djelo umjetnika najvjerojatnije su inspirirani romanom Slika Doriana Greya Oscara Wildea i kratkom pričom Ovalni portret Edgara Allana Poea, dok su motivi seksualnoga karaktera inspirirani radom Psychopathia sexualis Richarda Freiherra von Kraffta-Ebinga. Ne samo da su književnici bili inspirirani istim djelima već je i sama novela Lud slikar intertekstualno preradila Tanizakijevo Tetoviranje prilagodivši motive korejskim realijama i učinivši strukturu kompleksnijom.

Ključne riječi: moderna japanska književnost, moderna korejska književnost, Tanizaki Jun'ichirō, Kim Dong-in, Tetoviranje (Shisei), Lud slikar (Kwanghwasa) 